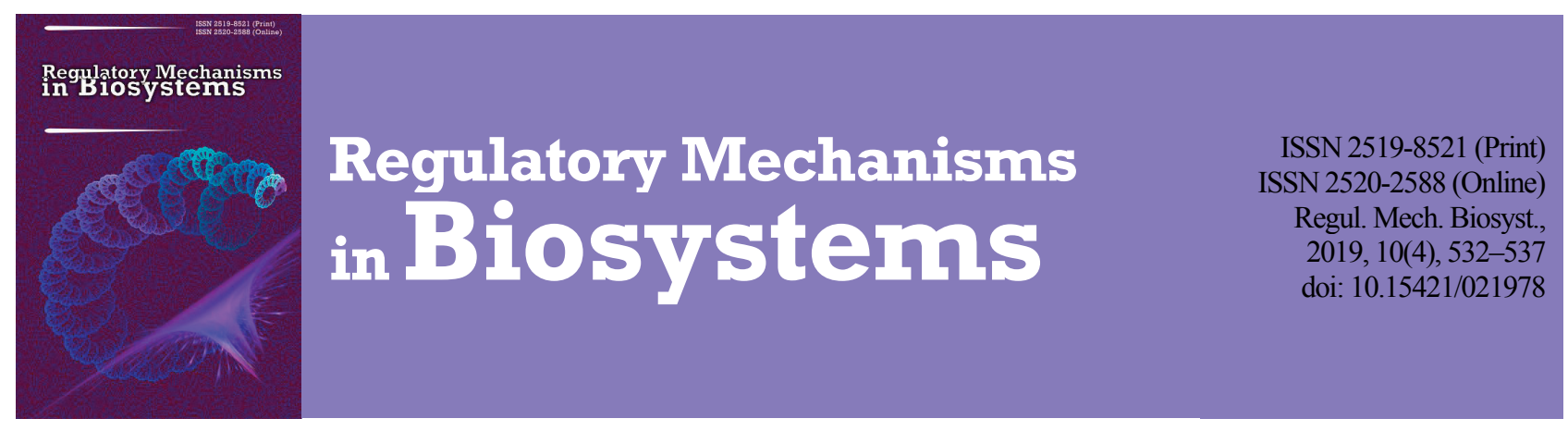

\title{
Contamination of hen manure with nine antibiotics in poultry farms in Ukraine
}

\author{
L. V. Shevchenko*, Y. V. Dobrozhan**, V. M. Mykhalska*, T. Y. Osipova*, V. V. Solomon* \\ *National University of Life and Environmental Sciences of Ukraine, Kyiv, Ukraine \\ **State Research Institute for Laboratory Diagnostics and Veterinary and Sanitary Expertise, Kyiv, Ukraine
}

Article info

Received 27.09.2019

Received in revised form 24.10.2019

Accepted 25.10.2019

National University of Life and Environmental Sciences of Ukraine, Heroïv Oborony st,

15, Kyiv, 03041, Ukraine.

Tel.: +38-050-193-10-29.

E-mail: shevchen-

ko_laris@ukr.net

State Research Institute

for Laboratory Diagnostics and Veterinary and Sanitary Expertise, Donetska st., 30, Kyiv, 02000, Ukraine. Tel.: +38-093-733-95-68

E-mail:alamerster@gmail.com

\begin{abstract}
Shevchenko, L. V., Dobrozhan, Y. V., Mykhalska, V. M., Osipova, T. Y., \& Solomon, V. V. (2019). Contamination of hen manure with nine antibiotics in poultry farms in Ukraine. Regulatory Mechanisms in Biosystems, 10(4), 532-537. doi:10.15421/021978
\end{abstract}

The problem of processing, use and utilization of poultry manure contaminated with antibiotics remains unsolved not only Ukraine but around the world, and theatment and prevention of highly contagious infectious diseases among birds requires antibacterial medication use. By liquid chromatography, 293 hen manure samples of 12 Ukrainian industrial flocks of poultry farms were studied. The residual content of 9 antibiotics in the hen manure was found, including $38.2 \%$ of tetracycline preparations (doxycycline, oxytetracycline, tetracycline and chlortetracycline), fluoroquinolone (enrofloxacin and norfloxacin) including combinations of incompatible tetracyclines and fluoroquinolones, broad-spectrum penicillins (amoxicillin), fenicols (florfenicol), macrolides (tylosin) and one sulfanilamide preparation (sulfametazine). The most common antibiotics in hen manure of Ukrainian industrial flocks of poultry farms are the antibiotics of the tetracycline group, the main one being doxycycline. A high correlation was determined between the release of doxycycline with eggs and hen manure after the preparation was used perorally in preventive and therapeutic doses. Time of complete excretion of doxycycline from the hen body at the preventive dose $(50 \mathrm{mg} / \mathrm{L}$ of water for 7 days) was 14 days for manure, 8 days for eggs, following its withdrawal, and at the therapeutic dose $(100 \mathrm{mg} / \mathrm{L}$ of water for 7 days ) - 20 days for manure, and 9 days for eggs, following its withdrawal. The perspective of using the obtained data about the duration of excretion of doxycycline with hen manure consists in confirmation of the time of the antibiotic's excretion with manure following its use for preventive or therapeutic purpose, which will help in controlling it as a source of environmental pollution. The time of doxycycline excretion from the body of hens with eggs and manure may be used practically by professionals in veterinary medicine in the case of prescribing or replacing antibiotics for treatment of infectious diseases of poultry to prevent the combination of incompatible preparations in the body and manure. The obtained experimental data may form the basis for the development of national regulations on the processing, usage and utilization of manure of hens under treatment with antibiotics.

Keywords: antibiotics; preventive and therapeutic doses; doxycycline; edible hen eggs; laying hens; manure.

\section{Introduction}

Intensive technologies in poultry farming imply a significant concentration of poultry in limited territories, which creates the risk of infectious and invasive diseases that eventually result in reduced productivity, quality and safety of production, loss of poultry and economic losses (Mund et al., 2017). In order to reduce the risk of spreading infectious diseases of animals in the world, including in Ukraine, a significant arsenal of antibacterial agents is used, including antibiotics (Boyko \& Brygadyrenko, 2017; Tang et al., 2017). Their worldwide production continues to grow, with total annual use reaching 100,000 to 200,000 tonnes (Gelband et al., 2015). In 2030, the antibiotic consumption in the world is predicted to be $200 \%$ higher than in 2015, with the highest increase in its use occurring in low- and average-income countries (Cycoń et al., 2019). In the last few decades, the use of antibiotics in animal feed as productivity stimulants has raised the potential for the development and transmission of resistance to a number of conditionally pathogenic and pathogenic microorganisms that can cause diseases and death among humans (Lee et al., 2017). Therefore, in Europe, a large number of countries have banned the use of antibiotics in animal feed as productivity stimulants (Dixon, 2000); however, in epizootic conditions occurring sporadically in different poultry enterprises, especially in the treatment of infectious diseases such as salmonellosis (Parry \& Threlfall, 2008; Chen et al. 2013), colibacillosis (Omer et al., 2010), pasteurellosis (El-Ghany et al., 2018), clostridiosis, listeriosis (Agunos et al., 2012), staphylococcosis, streptococcosis, mycoplasmosis, pseu532 domonosis, and others, alternatives to antibiotics are hard to find (Zaugolnikova \& Vistovskaya, 2016). Today, the problem of finding effective means of controlling poultry infectious diseases is solved through the development and use of specific prophylaxis (vaccines), as well as nonspecific drugs such as probiotics, prebiotics, postbiotics, hepatoprotectors and nanopreparations (Ghosh et al., 2016; Rios et al., 2016; Ghosh et al., 2019). However, all these measures do not provide a high guarantee in the controlling infectious diseases of animals. Therefore, the use of antibiotics in animal husbandry, including poultry, even for therapeutic purposes in the short term does not completely allows withdrawal of their introduction into the environment with manure and wastewater and requires detailed studies on the period of complete excretion depending on their use.

The objective of our research was the analysis of the contamination of the manure of hens in poultry farms in Ukraine with antibacterial drugs and determination of the duration of excretion of the most common antibiotic with the manure and eggs depending on the dose of administration.

\section{Materials and methods}

At the first stage of the research, withinthea period from 2013 to 2018, the representatives of the State Research Institute for Laboratory Diagnostics and Veterinary Expertise in accordance with the Program for State Veterinary and Sanitary Control of Salmonellosis in Broilers, Meat Turkeys, Laying Hens and Breeding Poultry (Hens and Turkeys) in the Poultry Farms of Ukraine for 2014-2018 (Nakaz, 2013), average 
samples of excrements were taken 12 poultry farms (at 11 poultry farms samples of manure were taken from 24 hen houses and at one - from 29 hen houses) specializing in the production of eggs.

The residues of the following drugs were determined in 293 samples of hen manure: tylosin, streptomycin, tetracycline, oxytetracycline, chlortetracycline, penicillin, amoxicillin, amoxicillin sulfamerazine, sulfamethoxazole, sulfamethoxypyridazine, sulfathiazole, sulfameter, sulfanilamide, colistin, nalidixic acid, thiamulin, trimethoprim.

At the second stage of research, we studied the dynamics of excretion of residual content of doxycycline as the most common antibiotic in hens' manure in Ukrainian poultry farms.

The experiment on laying hens was carried out in compliance with the requirements of the European Convention for the Protection of Vertebrate Animals Used for Scientific Experiments or Other Scientific Purposes, 1986, as well as the Law of Ukraine "On the Prevention of Cruelty to Animals" of 21.02.2006 No. 3447-IV as amended on 04.08.2017. The experiment was conducted based on the vivarium of the Faculty of Veterinary Medicine of the National University of Life and Environmental Sciences of Ukraine.

For the experiment, we used $20 \mathrm{Hy}$-Line white cross laying hens aged 35 weeks at the peak of egg-laying (95\%). The hens were divided into two groups according to the principle of analog groups: 10 individuals in each, doxycycline (produced by O.L.KAR animal health, Ukraine) in the preventive dose of $50 \mathrm{mg} / \mathrm{L}$ of water (7 days) was given to the first group, and the therapeutic dose of $100 \mathrm{mg} / \mathrm{L}$ of water (7 days) was given to the second group of hens. Before the experiment, the manure and eggs from hens of both groups were monitored for antibacterial drug residues. After confirmation of absence of contamination of the selected materials with antimicrobial agents, the experiment was started.

The experiment lasted for 30 days, during which daily samples of manure and eggs were collected by three samples from each group for the control of the residual doxycycline content. Samples for the study were taken at the same time in the morning before feeding. Laying hens were kept in two-tier battery cages, five individuals per one cage. Feeding of hens of both groups was carried out with full-fledged compound feed, which corresponded to the need for nutrients and biologically active substances, at the rate of $115 \mathrm{~g}$ per an individual daily with daily monitoring of residues.

Liquid chromatographs with a Waters double mass spectrometric detector (Alliance XE and Xevo model) (USA) were used to study the residual content of antibacterial drugs in the manure and eggs of hens. The chromatograph was equipped with a SunFire C18 analytical column, $50 \times 5 \mu \mathrm{m}$ for Alliance XE and ACQUITY UPLC ${ }^{\circledR}$ BEH C18, $1.7 \mu \mathrm{m}, 2.1 \times 100 \mathrm{~mm}$ for Xevo, double quadrupole mass spectrometer, positive ionization electrospray and MasLynx software for calculating results (Abramov et al., 2008; Novozhytska et al., 2014).

Statistical processing of the obtained results was performed with the calculation of the arithmetic mean (x) and the error of the arithmetic mean $(\mathrm{m})$ using regression and correlation analyzes in the ANOVA program, the difference was considered to be significant at $\mathrm{P}<0.05$ (taking into account the Bonferroni correction).

\section{Results}

Determination of residual content of antibacterial drugs in hens' manure in the poultry farms of Ukraine. As shown by the results of studies, $38.6 \%$ of samples of hens' manure contained residues of antibacterial drugs. The majority of them were represented by antibiotics (112 samples), accounting for $38.2 \%$ of the total number of the tested samples and $99.1 \%$ of the total number of positive ones (Table 1 ).

Only one sample of manure contained a preparation of the group of sulfanilamides - sulfamethazine, indicating that veterinary medicine for the prevention of infectious diseases in birds prefers antibiotics (Table 1).

The main group of antibiotics found in excrements of laying hens was tetracyclines, which accounted for $21.1 \%$ of the total and almost $54.8 \%$ of the positive samples. Of the tetracycline group, doxycycline, oxytetracycline, tetracycline, and chlortetracycline were found in the manure. Doxycycline was the most common antibiotic in the poultry manure, which accounted for $46.0 \%$ of all positive samples and $83.9 \%$ among the tetracycline group antibiotics. Antibiotics of the fluoroquinolones group, including enrofloxacin and norfloxacin, ranked second in terms of frequency of detection in hen manure. The proportion of fluoroquinolones in hen manure was more than $15.3 \%$ and almost $39.8 \%$ of the positive samples. Enrofloxacin occured most frequently among fluoroquinolones in the hens' manure, which was confirmed in $86.7 \%$ of cases, whereas norfloxacin only in $13.3 \%$ of samples. Of the broadspectrum penicillin antibiotics, amoxicillin was detected in two samples, and florfenicol of the fenicols group - in two samples.

Table 1

Antimicrobial drug residues in hen manure $(n=293)$

\begin{tabular}{lcccc}
\hline Drug name & $\begin{array}{c}\text { Number of } \\
\text { positive samples, } \\
\text { pieces }\end{array}$ & $\begin{array}{c}\text { At \% of the total } \\
\text { number of } \\
\text { samples, } \%\end{array}$ & $\begin{array}{c}\text { At \% per } \\
\text { positive } \\
\text { samples, } \%\end{array}$ & $\begin{array}{c}\text { Lim, } \\
\text { mcg/kg }\end{array}$ \\
\hline Doxycycline & 52 & 17.7 & 46.0 & $11.0-318.0$ \\
Oxytetracycline & 5 & 1.7 & 4.4 & $30.6-84.2$ \\
Tetracycline & 4 & 1.4 & 3.5 & $37.9-78.4$ \\
Chlortetracycline & 1 & 0.3 & 0.9 & 71.7 \\
Enrofloxacin & 39 & 13.3 & 34.5 & $22.0-317.0$ \\
Norfloxacin & 6 & 2.0 & 5.3 & $37.2-116.0$ \\
Amoxicillin & 2 & 0.7 & 1.8 & $46.0-149.0$ \\
Florfenicol & 2 & 0.7 & 1.8 & $83.0-469.0$ \\
Tylosin & 1 & 0.3 & 0.9 & 64.2 \\
Sulfamethazine & 1 & 0.3 & 0.9 & 20.0 \\
\hline \multicolumn{5}{c}{ Including antibiotic combinations } \\
\hline Doxycycline + & 18 & 6.1 & 15.9 & $21.6-100.5$ \\
Enrofloxacin & 18 & \multicolumn{5}{c}{$51.1-317.0$} \\
\hline
\end{tabular}

The results of studies on manure of industrial flocks give reason to consider doxycycline as one of the most common antibiotics used in Ukraine for the treatment and prevention of infectious diseases in industrial flocks of hens.

Dynamics of residual doxycycline content in eggs and manure at preventive and therapeutic doses. The administration of doxycycline to laying hens in industrial flocks orally in the preventive dose causes its uneven accumulation in eggs and manure (Table 2). The highest levels of doxycycline accumulation in eggs and hen manure were recorded on the 5th and 7th days. After the withdrawal of doxycycline, its residual level in eggs and manure was significantly decreasing until it was not detected in eggs on the 8th day, and in the manure - on the 14th day.

During provision of the therapeutic dose of doxycycline to hens, the highest accumulation was observed in eggs on the 2nd, 4th, 5th and 7th days, and in the manure - on the 1st, 2nd, and 7th day. After the withdrawal of doxycycline, its level gradually decreases in the hen eggs until the 9th day, and in the manure - to the 20th day respectively (Table 3). Use of correlation and regression analyses in the study showed that the residual content of doxycycline in the manure and eggs of industrial flocks at the dose of $50 \mathrm{mg} / \mathrm{L}$ of water correlated with each other $(\mathrm{r}=$ $0.861 \pm 0.110, \mathrm{P}<0.01)$. The regression line shows that there is a direct linear relationship between the residual doxycycline content in the manure and eggs of hens. A similar analysis was performed for values characterizing the intensity of excretion of doxycycline with eggs and manure at the dose of $100 \mathrm{mg} / \mathrm{L}$ of water for seven days. The values of the residual content of doxycycline in the manure and eggs in this case also correlate with each other, with the correlation coefficient $(r=0.856$ $\pm 0.100, \mathrm{P}<0.01$, Fig. 2). The regression line shows that there is a direct linear relationship between the residual doxycycline content in eggs and manure at its use in the the therapeutic dose.

\section{Discussion}

Treatment and prevention of infectious diseases include the widespread use of antibacterial drugs in poultry farming, which in turn causes antibiotics of different groups and sulfanilamide preparations to enter the manure (Table 1) and their penetration into soils, industrial sewerage, surface and groundwaters, drinking water (Awad et al., 2014; Hou et al., 2015).

Contamination of agroecosystem components with various antibacterial agents, including tetracycline and fluoroquinolone antibiotics, and sulfanilamide preparations is a significant problem not only in Ukraine 
but worldwide (Li et al., 2011, 2016; Wei et al., 2016) because their impact on the environment increases and causes emergence of antibiotic-resistant strains of microorganisms.

Table 2

Dynamics of residual doxycycline in eggs and hen manure at a dose of $50 \mathrm{mg} / \mathrm{L}$ of water $(\mathrm{x} \pm \mathrm{m}, \mathrm{n}=3)$

\begin{tabular}{ccc}
\hline Research period, day & Eggs, mkg/kg & Manure, $\mathrm{mkg} / \mathrm{kg}$ \\
\hline 1 & Feeding doxycycline \\
2 & $381 \pm 34$ & $4707 \pm 424$ \\
3 & $827 \pm 49$ & $7391 \pm 587$ \\
4 & $255 \pm 28$ & $1494 \pm 98$ \\
5 & $505 \pm 46$ & $1076 \pm 462$ \\
6 & $1806 \pm 117$ & $10620 \pm 2313$ \\
7 & $486 \pm 49$ & $1082 \pm 346$ \\
& $1134 \pm 81$ & $1509 \pm 393$ \\
\hline 1 & After withdrawal of doxycycline \\
2 & $114 \pm 49$ & $521 \pm 213$ \\
3 & $129 \pm 6$ & $459 \pm 99$ \\
4 & $124 \pm 4$ & $128 \pm 35$ \\
5 & $192 \pm 10$ & $143 \pm 4$ \\
6 & $111 \pm 14$ & $278 \pm 32$ \\
7 & $57 \pm 6$ & $135 \pm 13$ \\
8 & $22 \pm 4$ & $114 \pm 11$ \\
9 & $8 \pm 8$ & $99 \pm 19$ \\
10 & $<3^{*}$ & $161 \pm 28$ \\
11 & - & $120 \pm 34$ \\
12 & - & $90 \pm 34$ \\
13 & - & $63 \pm 37$ \\
14 & - & $82 \pm 12$ \\
15 & - & $29 \pm 10$ \\
\hline
\end{tabular}

Note: * - the LOQ (limit of quantification) was set at the concentration of $3 \mu \mathrm{g} / \mathrm{kg}$ for eggs and of $20 \mu \mathrm{g} / \mathrm{kg}$ for manure.
Table 3

Dynamics of residual doxycycline in eggs and hen manure at the dose of $100 \mathrm{mg} / \mathrm{L}$ of water $(\mathrm{x} \pm \mathrm{m}, \mathrm{n}=3)$

\begin{tabular}{|c|c|c|}
\hline Research period, day & Eggs, $\mathrm{mkg} / \mathrm{kg}$ & Manure, $\mathrm{mkg} / \mathrm{kg}$ \\
\hline \multicolumn{3}{|c|}{ Feeding doxycycline } \\
\hline 1 & $866 \pm 93$ & $8017 \pm 111$ \\
\hline 2 & $1650 \pm 354$ & $13675 \pm 369$ \\
\hline 3 & $338 \pm 33$ & $1052 \pm 169$ \\
\hline 4 & $1685 \pm 133$ & $2792 \pm 947$ \\
\hline 5 & $2628 \pm 464$ & $11003 \pm 1273$ \\
\hline 6 & $572 \pm 46$ & $1543 \pm 163$ \\
\hline 7 & $1510 \pm 67$ & $14178 \pm 2188$ \\
\hline \multicolumn{3}{|c|}{ After withdrawal of doxycycline } \\
\hline 1 & $220 \pm 80$ & $1990 \pm 473$ \\
\hline 2 & $187 \pm 120$ & $173 \pm 66$ \\
\hline 3 & $307 \pm 112$ & $379 \pm 110$ \\
\hline 4 & $175 \pm 52$ & $337 \pm 18$ \\
\hline 5 & $128 \pm 27$ & $295 \pm 15$ \\
\hline 6 & $28 \pm 3$ & $81 \pm 9$ \\
\hline 7 & $16 \pm 1$ & $243 \pm 34$ \\
\hline 8 & $32 \pm 6$ & $212 \pm 28$ \\
\hline 9 & $3 \pm 3$ & $154 \pm 19$ \\
\hline 10 & $<3$ & $143 \pm 21$ \\
\hline 11 & - & $116 \pm 12$ \\
\hline 12 & - & $116 \pm 7$ \\
\hline 13 & - & $81 \pm 17$ \\
\hline 14 & - & $48 \pm 3$ \\
\hline 15 & - & $41 \pm 5$ \\
\hline 16 & - & $39 \pm 5$ \\
\hline 17 & - & $45 \pm 4$ \\
\hline 18 & - & $35 \pm 3$ \\
\hline 19 & - & $33 \pm 4$ \\
\hline 20 & - & $24 \pm 3$ \\
\hline 21 & - & $<20$ \\
\hline
\end{tabular}

Note: see Table 2

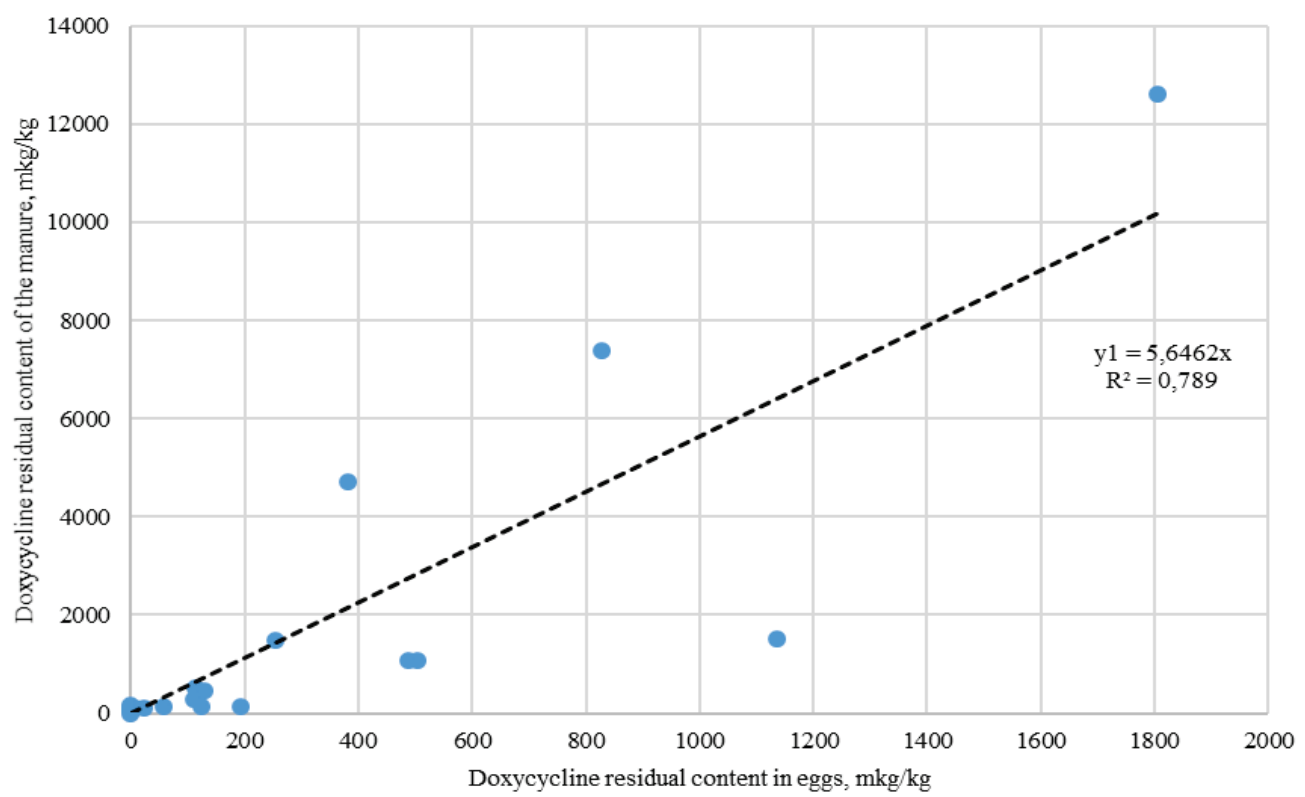

Fig. 1. Dependence of doxycycline content in eggs on its content in the hen manure at the dose of $50 \mathrm{mg} / \mathrm{L}$ of water $(\mathrm{n}=22)$

A total of $75 \%$ of antibiotics are the prevailing source of environmental pollution, including tetracycline and fluoroquinolone, which enter the body of animals and birds, pass unchanged through their digestive apparatus and are excreted not only with food (Bayer et al., 2017a, b), but also directly into the excrements used as organic fertilizers (Badea et al., 2013; Chitescu et al., 2013; Zhang et al., 2016).

The results of our research confirm the abovementioned statistics. According to the frequency of detecting the antibacterial preparations in the manure in the poultry farms of Ukraine, they can be placed in the following row: tetracyclines $(46.0 \%)>$ fluoroquinolones $(15.0 \%)>$ penicillins $=$ fenicols $>$ macrolides $=$ sulfanilamides. The results largely coincide with those of other researchers who determined residues of veterinary drugs in animal manure (An et al., 2015; Zhang et al., 2015), as well as in soil layers in eastern China over use of animal manure as organic fertilizer. Antibiotics in soil layers at the depth of $20-40$ and $40-60 \mathrm{~cm}$ were found to a greater extent than at the depth of 0-20 cm (Wei et al., 2016), which indicates their significant migration ability.

Antibiotics of tetracycline group are the commonest antibiotics used in animal husbandry, including poultry farming in Ukraine, which is related to their advantages over other drugs, namely, high activity against a wide range of microorganisms, including gram-positive and gram-negative bacteria, chlamydia, mycoplasma, rickettsiae, and protozoa, at relatively low cost and the property to act as stimulators of growth and productivity at sub-therapeutic levels in animals (Chopra \& Roberts, 2001). 


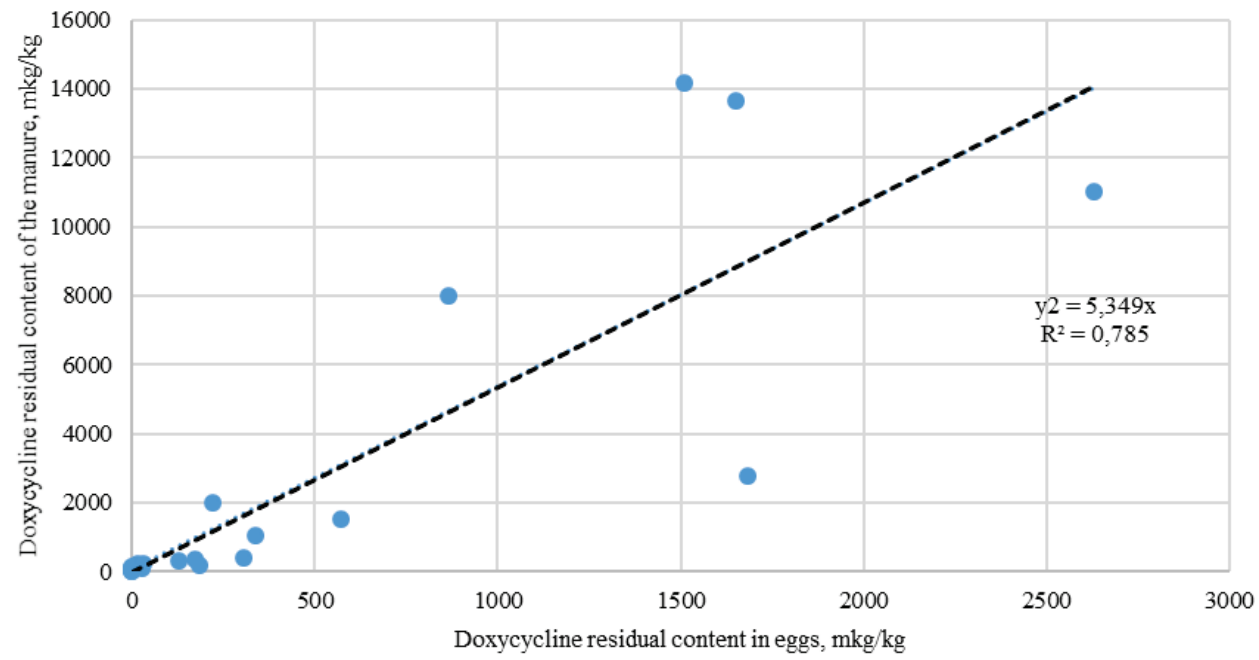

Fig. 2. Dependence of doxycycline content in eggs on its content in the hen manure at the dose of $100 \mathrm{mg} / \mathrm{L}$ of water $(\mathrm{n}=28)$

The large residual concentrations of doxycycline that we found in the manure of separate poultry farms in Ukraine indicate probably their therapeutic use in poultry in case of infectious diseases, and insignificant ones the use for preventive purposes or end of their withdrawal period. In this case, tetracycline antibiotics in industrial flocks for prevention purposes can be used only over the growth phase, since the residual content of these antibiotics in eggs is not allowed by the national standard (DSTU 5028: $200,2010)$. During the analysis of the residual content of antibiotics in the hens in different farms of Ukraine, we found samples of manure with a combination of incompatible antibiotics of tetracyclines and fluoroquinolones, namely doxycycline and enrofloxacin. We assume that the poultry farms applied alternate use of several antibiotics for preventive or therapeutic purposes, without taking into account the period of their complete withdrawal from the body of poultry in feces. This situation is possible due to the lack of scientifically valid data on the duration of excretion of antibiotics from the body of animal (hen manure), and regulatory documents for the control of residual content of antibacterial substances in the manure of animals.

The use of tetracycline and fluoroquinolone antibiotics in infectious diseases in hens is associated with a different mechanism of action. The mechanism of action of enrofloxacin against the salmonellosis pathogen is to block the activity of the gyrase enzyme, on which the replication of DNA helix in the nucleus of the bacterial cell depends (Mark \& Mitchell, 2006; Trouchon \& Lefebvre, 2016). The mechanism of action of doxycycline in the body is associated with impaired protein synthesis in bacterial cells. Doxycycline penetrates the bacterial cell, interacts with the aminoacyl center of the ribosomal 50S-subunit, interferes with the peptidyltranslocation response, preventing tRNAs from transporting new amino acids to the ribosome from developing protein chain (Schnappinger \& Hillen, 1996).

Detection of residual content of antibiotics of groups of fluoroquinolones, macrolides, and sulfanilamide preparations in the manure implies their ingress into the soil (Hu et al., 2010; Yang et al., 2010; Zhou et al., 2012-2013). This has been especially relevant over the few recent decades, since after antibiotics ingress into the soil, crops are exposed to their effect (Pan et al., 2014; Ahmed et al., 2015; Franklin et al., 2015) which depends on the physicochemical properties, sorption potential of antibacterials and environmental conditions (Dolliver et al., 2007; Azanu et al., 2016). Even if some antibiotics become degraded to certain extent, most of them are replaced due to constant ingress ( $\mathrm{Li}$ et al., 2012), thus creating the conditions for the continuous circulation of antibiotics in the environment (Herklotz et al., 2010; Kang et al., 2013; Cycoń et al., 2019).

Antibiotics which become introduced into soil with poultry manure can accumulate in plants used as food (Chowdhury et al., 2016; Hussain et al., 2016). The conversion rate of antimicrobials into plants was determined to be at the level of $0.4-54.3 \%$ (Park et al., 2016; Zhang et al., 2017). Foods of plant origin which contain antibiotic residues can cause allergic reactions, chronic toxic effects due to prolonged exposure and even impaired digestive function in humans (Gullberg et al., 2011;
Schuijt et al., 2013; Azanu et al., 2016). In order to prevent the ingress into the environment, including antibiotics into the soil, it is necessary to take into account the time of their excretion with manure. The dynamics of doxycycline excretion in the content of eggs and manure determined the experiment indicate that this antibiotic can be introduced into the environment for a much longer period with manure compared to eggs. The residual content of doxycycline in eggs and manure during the period of its administration with water has a large range of fluctuations, which is associated with the features of its absorption in the digestive apparatus, as well as high ability to bind to plasma proteins, which reaches $80-90 \%$. Doxycycline is rapidly distributed to most body fluids, including bile, paranasal secretions, pleural, synovial, and ascitic fluids, and is excreted slowly. A significant amount of doxycycline is excreted unchanged from the organism of animals with feces, approximately $40 \%$ with urine (Yang et al., 2016).

The data obtained by us indicate that the excretion of doxycycline with manure of hens of industrial flocks is more dependent on its dose, whereas its excretion with eggs is much less dependent on the dose. Therefore, in case of necessity of changing a medication for treatment or prevention of infectious diseases, veterinary medicine often uses only period of its withdrawal, which was determined for food products of animal origin. Our studies do not contradict the findings of other scientists (Gajda \& Posyniak, 2015), but there are some differences in the duration of doxycycline excretion with eggs due to different doses, routes of administration, and duration of administration of this antibiotic to laying hens. Excretion of doxycycline from hens with manure at the preventive dose $(50 \mathrm{mg} / \mathrm{L}$ of water for 7 days) lasts up to 14 days, and at the therapeutic dose $(100 \mathrm{mg} / \mathrm{L}$ of water $)$ - up to 20 days following its withdrawal. Based on the data obtained, it is possible to predict the duration of excretion of doxycycline with hen's manure, depending on its oral dose.

As for the excretion of doxycycline in the eggs, a pattern can not be established, since the duration of excretion of this antibiotic with eggs did not significantly depend on its dose and was 8 days for preventive and 9 days for therapeutic doses following its withdrawal. However, data from other researchers indicate little dependence, and it differs more by individual egg components: yolk and protein and is explained by the lipophilicity of the antibiotic (Yoshimura et al., 1991; Vandenberge et al., 2012).

\section{Conclusions}

Studies have shown that in Ukraine, the main antibiotics that contaminate manure are tetracyclines and fluoroquinolones. The most common antibiotic found in hen manure is doxycycline. The use of doxycycline with water in laying hens causes dose-dependent excretion with eggs and manure. The excretion of doxycycline with eggs correlates with the parameters of excretion with manure, and is 8 days for prophylactic dose and 9 days for therapeutic dose following its withdrawal. The duration of excretion of doxycycline from laying hens at the preventive dose $(50 \mathrm{mg} / \mathrm{L}$ of water for 7 days) was 14 days and 20 days for therapeutic dose $(100 \mathrm{mg} / \mathrm{L}$ 
of water for 7 days) following its withdrawal. This should be taken into account in cases of antibiotic replacement in the treatment of infectious diseases of poultry, as well as the disposal of manure from hens in case of using this drug. Experimental data may also form the basis for the development of national regulations on the use, recycling or disposal of hen manure following therapeutic or prophylactic use of antibiotics.

\section{References}

Abramov, A. V., Novozhytska, Y. M., \& Ivanova, O. V. (2008). Vyznachennia ftorkhinoloniv v produktakh tvarynnoho pokhodzhennia metodom ridynnoi khromatohrafii [Determination of fluoroquinolones in products of animal origin by liquid chromatography]. Kyiv (in Ukrainian).

Agunos, A., Léger, D., \& Carson, C. (2012). Review of antimicrobial therapy of selected bacterial diseases in broiler chickens in Canada. The Canadian Veterinary Journal - La Revue Veterinaire Canadienne, 53(12), 1289-1300

Ahmed, M. B. M., Rajapaksha, A. U., Lim, J. E., Vu, N. T., Kim, I. S., Kang, H. M., Lee, S. S., \& Ok, Y. S. (2015). Distribution and accumulative pattern of tetracyclines and sulfonamides in edible vegetables of cucumber, tomato, and lettuce. Journal of Agricultural and Food Chemistry, 63, 398-405.

An, J., Chen, H. W., Wei, S. H., \& Gu, J. (2015). Antibiotic contamination in animal manure, soil, and sewage sludge in Shenyang, Northeast China. Environmental Earth Sciences, 74, 5077-5086.

Awad, Y. M., Kim, S. C., El-Azeem, S. A. M. A., Kim, K. H., Kim, K. R., Kim, K., Jeon, C., Lee, S. S., \& Ok, Y. S. (2014). Veterinary antibiotics contamination in water, sediment, and soil near a swine manure composting facility. Environmental Earth Sciences, 71, 1433-1440.

Azanu, D., Mortey, C., Darko, G., Weisser, J. J., Styrishave, B., \& Abaidoo, R. C. (2016). Uptake of antibiotics from irrigation water by plants. Chemosphere, $157,107-114$.

Badea, M. N., Diacu, E., \& Radu, V. M. (2013). Influence of antibiotics on copper uptake by plants. Revista De Chimie, 64, 684-687.

Bayer, E., Novozhitskaya, Y., Shevchenko, L., \& Mykhalska, V. (2017a). Vyznachennia vmistu antybiotykiv ta sulfanilamidnykh preparativ u molotsi skryninhovym metodom [Determination of the content of antibiotics and sulfanilamide drugs in milk by screening method]. Ukrainian Journal of Ecology, 7, $576-582$ (in Ukrainian).

Bayer, E., Novozhitskaya, Y., Shevchenko, L., \& Mykhalska, V. (2017b). Monitorynh zalyshkiv veterynarnykh preparativ u kharchovykh produktakh [Monitoring of residues of veterinary preparations in food products]. Ukrainian Journal of Ecology, 7(3), 251-257 (in Ukrainian).

Boyko, A. A., \& Brygadyrenko, V. V. (2017). Changes in the viability of Strongyloides ransomi larvae (Nematoda, Rhabditida) under the influence of synthetic flavourings. Regulatory Mechanisms in Biosystems, 8(1), 36-40.

Chen, H. M., Wang, Y., Su, L. H., \& Chiu, C. H. (2013). Nontyphoid Salmonella infection: Microbiology, clinical features, and antimicrobial therapy. Pediatrics and Neonatology, 54, 147-152.

Chitescu, C. L., Nicolau, A. I., \& Stolker, A. A. (2013). Uptake of oxytetracycline, sulfamethoxazole and ketoconazole from fertilised soils by plants. Food Additives and Contaminants, Part A, 30, 1138-1146.

Chopra, I., \& Roberts, M. (2001). Tetracycline antibiotics: Mode of action, applications, molecular biology, and epidemiology of bacterial resistance. Microbiology and Molecular Biology Reviews, 65, 232-260.

Chowdhury, F., Langenkämper, G., \& Grote, M. (2016). Studies on uptake and distribution of antibiotics in red cabbage. Journal für Verbraucherschutz und Lebensmittelsicherheit, 11, 61-69.

Cycoń, M., Mrozik, A., \& Piotrowska-Seget, Z. (2019). Antibiotics in the soil environment-degradation and their impact on microbial activity and diversity. Frontiers in Microbiology, 10, 338.

Dixon, B. (2000). Antibiotics as growth promoters: Risks and alternatives. ASM News, 66(5), 264.

Dolliver, H., Kumar, K., \& Gupta, S. (2007). Sulfamethazine uptake by plants from manure-amended soil. Journal of Environmental Quality, 36, 1224-1230.

El-Ghany, W. A., Ahmed, H. A., \& Qandoos, A. Z. (2018). Characterization of Pasteurella multocida in different Egyptian chicken flocks. Journal of Animal and Plant Sciences, 28, 1693-1700.

Franklin, A. M., Williams, C. F., Andrews, D. M., Woodward, E. E., \& Watson, J. E. (2015). Uptake of three antibiotics and an antiepileptic drug by wheat crops spray irrigated with wastewater treatment plant effluent. Journal of Environmental Quality, $45,546$.

Gajda, A., \& Posyniak, A. (2015). Doxycycline depletion and residues in eggs after oral administration to laying hens. Food Additives and Contaminants: Part A, 32(7), 1116-1123.

Ghosh, C., Sarkar, P., Issa, R., \& Haldar, J. (2019). Alternatives to conventional antibiotics in the era of antimicrobial resistance. Trends in Microbiology, 27(4), 323-338.
Gullberg, E., Cao, S., Berg, O. G., Ilbäck, C., Sandegren, L., Hughes, D., \& Andersson, D. I. (2011). Selection of resistant bacteria at very low antibiotic concentrations. PLoS Pathogens, 7, 1002158.

Herklotz, P. A., Gurung, P., Vanden, H. B., \& Kinney, C. A. (2010). Uptake of human pharmaceuticals by plants grown under hydroponic conditions. Chemosphere, 78, 1416-1421.

Hou, J., Wan, W. N., Mao, D. Q., Wang, C., Mu, Q. H., Qin, S. Y., \& Luo, Y. (2015). Occurrence and distribution of sulfonamides, tetracyclines, quinolones, macrolides, and nitrofurans in livestock manure and amended soils of Northern China. Environmental Science and Pollution Research, 22, 4545- 4554.

Hu, X. G., Zhou, Q. X., \& Luo, Y. (2010). Occurrence and source analysis of typical veterinary antibiotics in manure, soil, vegetables and groundwater from organic vegetable bases, Northern China. Environmental Pollution, 158, 2992-2998.

Hussain, S., Naeem, M., Chaudhry, M. N., \& Iqbal, M. A. (2016). Accumulation of residual antibiotics in the vegetables irrigated by pharmaceutical wastewater. International Journal of Environmental Research and Public Health, 8, 107-115.

Kang, D. H., Gupta, S., Rosen, C., Fritz, V., Singh, A., Chander, Y., Murray, H., \& Rohwer, C. (2013). Antibiotic uptake by vegetable crops from manureapplied soils. Journal of Agricultural and Food Chemistry, 61, 9992-10001.

Lee, J-Y, Han, G. G., Lee, H.-B., Lee, S.-M., Kang, S.-K., Jin, G.-D., Park J., Chae, B. J., Choi, Y. H., Kim, E. B., \& Choi, Y-J. (2017). Prohibition of antibiotic growth promoters has affected the genomic profiles of Lactobacillus salivarius inhabiting the swine intestine. PLoS ONE, 12(10), e0186671.

Li, C., Chen, J. Y., Wang, J. H., Ma, Z. H., Han, P., Luan, Y. X., \& Lu, A. X. (2015). Occurrence of antibiotics in soils and manures from greenhouse vegetable production bases of Beijing, China and an associated risk assessment. Science of the Total Environment, 521-522, 101-107.

Li, W. H., Shi, Y. L., Gao, L. H., Liu, J. M., \& Cai, Y. Q. (2012). Occurrence of antibiotics in water, sediments, aquatic plants, and animals from Baiyangdian Lake in North China. Chemosphere, 89, 1307-1315.

Li, Y. W., Wu, X. L., Mo, C. H., Tai, Y. P., Huang, X. P., \& Xiang, L. (2011). Investigation of sulfonamide, tetracycline, and quinolone antibiotics in vegetable farmland soil in the Pearl River Delta area, Southern China. Journal of Agricultural and Food Chemistry, 59, 7268-7276.

Mark, A., \& Mitchell, D. V. M. (2006). Enrofloxacin. Journal of Exotic Pet Medicine, 15(1), 66-69.

Mund, M. D., Khan, U. H., Tahir, U., Mustafa, B.-E., \& Fayyaz, A. (2017). Antimicrobial drug residues in poultry products and implications on public health: A review. International Journal of Food Properties, 20(7), 1433-1446.

Novozhytska, Y. M., Ivanova, O. V., \& Stupak, O. M. (2014). Vyznachennia antybiotykiv u produktakh tvarynnoho pokhodzhennia za dopomohoiu ridynnoho khromatomas-spektrometra [Determination of antibiotics in products of animal origin by liquid chromatomas spectrometer]. DNDILDVSE, Kyiv (in Ukrainian).

Omer, M. M., Abusalab, S. M., Gumaa, M. M., Mulla, S. A., Omer, E. A., Jeddah, I. E., AL-Hassan, A. M., Hussein, M. A., \& Ahmed, A. M. (2010). Outbreak of colibacillosis among broiler and layer flocks in intensive and semiintensive poultry farms in Kassala State, Eastern Sudan. Asian Journal of Poultry Science, 4, 173-181.

Pan, M., Wong, C. K. C., \& Chu, L. M. (2014). Distribution of antibiotics in wastewater-irrigated soils and their accumulation in vegetable crops in the Pearl River Delta, Southern China. Journal of Agricultural and Food Chemistry, 62, 11062-11069.

Park, S. B., Kim, S. J., \& Kim, S. C. (2016). Evaluating plant uptake of veterinary antibiotics with hydroponic method. Korean Journal of Soil Science and Fertilizer, 49, 242-250.

Parry, C. M., \& Threlfall, E. J. (2008). Antimicrobial resistance in typhoidal and nontyphoidal salmonellae. Current Opinion in Infectious Diseases, 21, 531-538.

Rios, A. C., Moutinho, C. G., Pinto, F. C., Del Fiol, F. S., Jozala, A., Chaud, M. V., Vila, M. M., Teixeira, J. A., \& Balcão, V. M. (2016). Alternatives to overcoming bacterial resistances: State-of-the-art. Microbiological Research, 191, 51-80.

Schnappinger, D., \& Hillen, W. (1996). Tetracyclines: Antibiotic action, uptake, and resistance mechanisms. Archives of Microbiology, 165(6), 359.

Schuijt, T. J., Poll, T., Vos, W. M., \& Wiersinga, W. J. (2013). The intestinal microbiota and host immune interactions in the critically ill. Trends Microbiology, 21, 221-229.

Tang, K. L., Caffrey, N. P., Nóbrega, D. B., Cork, S. C., Ronksley, P. E., Barkema, H. W., Polachek, A. J., Ganshom, H., Sharma, N., Kellner, J. D., \& Ghali, W. A. (2017). Restriction in the use of antibiotics in food animals and antibiotic resistance in food animals and humans - A systematic review and meta-analysis. The Lancet Planetary Health, 1(8), e316-e327.

Trouchon, T., \& Lefebvre, S. (2016). A review of enrofloxacin for veterinary use. Open Journal of Veterinary Medicine, 6, 40-58.

Vandenberge, V., Delezie, E., Huyghebaert, G., Delahaut, P., De Backer, P., Daeseleire, E., \& Croubels, S. (2012). Residues of sulfadiazine and doxycycline in egg matrices due to cross-contamination in the feed of laying hens and the possible correlation with physicochemical, pharmacokinetic and physiological parameters. Food Additives and Contaminants: Part A, 29(6), 908-917. 
Wei, R. C., Ge, F., Zhang, L. L., Hou, X., Cao, Y. N., Gong, L., Chen, M., Wang, R. $\&$ Bao, E. D. (2016). Occurrence of 13 veterinary drugs in animal manureamended soils in Eastern China. Chemosphere, 144, 2377-2383.

Yang, F., Si, H. B., Wang, Y. Q., Zhao, Z. S., Zhou, B. H., \& Hao, X. Q. (2016) Pharmacokinetics of doxycycline in laying hens after intravenous and oral administration. British Poultry Science, 57(4), 576-580.

Yang, J. F., Ying, G. G., Zhao, J. L., Tao, R., Su, H. C., \& Chen, F. (2010). Simultaneous determination of four classes of antibiotics in sediments of the Pearl Rivers using RRLC-MS/MS. Science of the Total Environment, 408, 3424 3432

Yoshimura, H., Osawa, N., Rasa, F. S. C., Hermawati, D., Werdiningsih, S., Isriyanthi, N. M. R., \& Sugimori, T. (1991). Residues of doxycycline and oxytetracycline in eggs after medication via drinking water to laying hens. Food Additives and Contaminants, 8(1), 65-69.

Zaugolnikova, M. A., \& Vistovskaya, V. P. (2016). Contamination of animal products by residual quantity of antibiotics. Acta Biologica Sibirica, 2(3), 9-20.

Zhang, H. B., Luo, Y. M., Wu, L. H., Huang, Y. J., \& Christie, P. (2015). Residues and potential ecological risks of veterinary antibiotics in manures and composts associated with protected vegetable farming. Environmental Science and Pollution Research, 22, 5908-5918.

Zhang, H. B., Zhou, Y., Huang, Y. J., Wu, L. H., Liu, X. H., \& Luo, Y. M. (2016) Residues and risks of veterinary antibiotics in protected vegetable soils following application of different manures. Chemosphere, 152, 229-237.

Zhang, H., Li, X., Yang, Q., Sun, L., Yang, X., Zhou, M., Deng, R., \& Bi, L. (2017). Plant growth, antibiotic uptake, and prevalence of antibiotic resistance in an endophytic system of pakchoi under antibiotic exposure. International Journal of Environmental Research and Public Health, 14(11), 1336.

Zhou, L. J., Ying, G. G., Liu, S., Zhao, J. L., Chen, F., Zhang, R. Q., Peng, F. Q., \& Zhang, Q. Q. (2012). Simultaneous determination of human and veterinary antibiotics in various environmental matrices by rapid resolution liquid chromatography - electrospray ionization tandem mass spectrometry. Journal of Chromatography A, 1244, 123-138.

Zhou, L. J., Ying, G. G., Liu, S., Zhao, J. L., Yang, B., Chen, Z. F., \& Lai, H. J. (2013). Occurrence and fate of eleven classes of antibiotics in two typical wastewater reatment plants in South China. Science of the Total Environment, 452-453, 365-376. 